\title{
EFFECTIVENESS OF A NATIONAL RESOURCE FUND IN COUNTERACTING THE RESOURCE CURSE
}

\author{
Yanina DYMITROWSKA \\ Poznań University of Economics and Business, Department of Macroeconomics and Development Research; \\ yanina.dymitrowska@ue.poznan.pl, ORCID: 0000-0002-2772-5971
}

\begin{abstract}
The objective of this article is to identify indicators that allow for assessing the effectiveness of resource funds in the context of the resource curse occurrence in countries rich in natural resources. At particular stages of the study, several research tasks were also carried out, which made it possible to achieve the goal - the concept of the resource fund was conceptualised, the types and functions of the fund were presented, the individual objectives of creating funds were assigned to the symptoms of the resource curse, the concept of the resource fund was referred to the sovereign wealth funds, and a system resource fund operates was also introduces.
\end{abstract}

Keywords: resource fund, resource curse, economic development, resource rich countries, Sovereign Wealth Fund.

\section{Introduction}

The development issues of countries rich in natural resources ${ }^{1}$ are important and actual, because many wealthy economies struggle with a resource curse $\mathrm{e}^{2}$. The paradox of plenty is a phenomenon of achieving worse results of economic development by countries specialising in the extraction and export of natural resources compared to countries whose resources are negligible, which commonly occurs (i.a. Auty, 2001; Sachs, and Warner, 2001; Neumayer, 2004; Bulte et al., 2005; Arezki, and van der Ploeg, 2007; Dymitrowska, 2015). In recent years, due to the fall and volatility of prices of strategically important natural resources, such as oil and natural gas, the problem is becoming more and more serious. The resource curse is not

\footnotetext{
${ }^{1}$ In this study, a country rich in natural resources is treated unambiguously with the concept of a country specialising in the extraction and export of natural resources and a country whose economy is based on the extraction and export of natural resources. At the same time, it is assumed that a country rich in natural resources is a country in which one of these conditions is met: the average annual revenues of the mining industry (in $\%$ of GDP) exceed $25 \%$, or $25 \%$ of the average annual exports are natural resources. More on this subject in: Dymitrowska, 2015, p. 50.

${ }^{2}$ Other common nomenclature in literature - paradox of plenty, curse of natural resources, curse of wealth.
} 
a law, but a strong tendency seen in many, but not all, countries exporting natural resources. Botswana, Chile, Indonesia, Malaysia, United Arab Emirates, Canada and Australia are mentioned in literature as countries that managed to avoid the curse (e.g. Auty, 1993; Sarraf, and Jiwanji, 2001; Acemoglu et al., 2001; Rasiah, and Shari, 2001; Fasano, 2002; Wright, and Czelusta, 2002; Larsen, 2005; Stevens, 2003a, 2003b; Stijns, 2005; Dymitrowska, 2015). Norway is the undisputed leader in the ranking of beneficiaries of abundance of natural resources. Based on an analysis of the economic policies used in these countries, some tools can be identified as important in counteracting the resource curse. One of the measures is the active policy of the National Resources Fund (NRF).

Many forms of funds have been created in recent years, and some countries have benefited significantly from their creation. An often-mentioned fund as an example of great success is the Government Pension Fund Global of Norway (i.a. Mikesell, 1997; Usui, 1997; Fasano, 2000; Frankel, 2010). At the same time, it should be noted that in many developing countries, natural resource funds have poor efficiency (e.g. Davis et al., 2001). Therefore, scientists' opinions on the importance of natural resource funds for the economic development of countries rich in natural resources are divided. Some researchers pay attention to the fact that the tasks carried out by the fund can be effectively performed through active state fiscal policy (e.g. Davis et al., 2001; Ossowski et al., 2008), and the resource fund, as one of the national stabilisation tools, is characterised by weak efficiency. Others (e.g. Devlin, and Lewen, 2002; Shabsigh, and Ilahi, 2007; Bagattini, 2011; Asik, 2017) see a positive relation between the activity of the NRF and counteracting the paradox of plenty. Still others question the possibility of using the tool effectively in those poorest countries rich in natural resources (e.g. Dymitrowska, 2015). There is also no unanimity as to the methodology for assessing the effectiveness of funds. Due to the use of different assessment criteria and divergent interpretations of the concept of the natural resource fund, the research results are ambiguous. In addition, it should be noted that the funds created in individual exporters of natural resources differ in terms of their functions, and the assumptions of the fund's activities change over time. There is no generally accepted rule regarding the method of creation and management of the NRF enabling its effective functioning. Therefore, a significant research gap is visible in the field of issues related to the national natural resource fund and assessment of the fund's effectiveness in counteracting the resource curse.

The main goal of this study is to distinguish indicators that allow for assessing the effectiveness of natural resource funds in the context of the resource curse in countries rich in natural resources. To achieve the goal, a number of research tasks have also been defined. These include: conceptualisation of the concept of an NRF, an indication of the types and functions of the fund, linking the individual tasks of the fund with signs of the resource curse, referring the concept of the NRF to sovereign wealth funds and presenting a system resource fund operates. 
The article consists of three parts, preceded by an introduction, and is summarised by main conclusions. The initial part presents the essence of the natural resource fund in the context of the paradox of plenty. Critical analysis of current scientific achievements has allowed the author to organise issues related to the NRF. The concept of the fund was also conceptualised. The motives for creating the fund and its types were described. Additionally, a general scheme describing how the fund functions was proposed. The second part analyses various methodologies and research results regarding the assessment of the effectiveness of an NRF in countries rich in natural resources. The last part refers to individual functions of the resource fund to the symptoms of the resource curse and presents the author's list of indicators relevant for assessing the effectiveness of natural resource funds in relation to individual functions and the tasks performed by them.

The study is theoretical. To prepare the article, foreign literature in English was mostly used. Materials provided by international organisations (including the World Bank, International Monetary Fund, International Forum of Sovereign Wealth Funds, Natural Resource Governance Institute, International Forum of Sovereign Wealth Funds) were also used.

\section{Essence of the National Resource Fund}

One of the main reasons for the resource curse in countries rich in natural resources is the volatility of commodity prices. In a situation where a country's economy is heavily dependent on revenues from their exports of natural resources, any sharp change in the price on the international natural resources market causes a collapse on the domestic market. It is noteworthy that the rapid increase in commodity prices also negatively affects the economic situation of their exporting country, contributing to the emergence of a Dutch disease and resource curse in the long run $^{3}$.

The first $\mathrm{NRFs}^{4}$ were created to stabilise the situation in a country rich in natural resources and to create a kind of buffer between changes on the global and domestic market. Therefore, in literature on the subject (Asik, 2017; Sugawara, 2017), the term stabilisation fund is often used to refer to the NRF. The stabilising function of the natural resource fund is implemented by setting a price limit for exported resources. If the price exceeds a certain threshold, the excess

\footnotetext{
${ }^{3}$ Dutch disease is a phenomenon involving the reduction of competitiveness, both in the country and abroad (and ultimately bankruptcy), of domestic enterprises from sectors not related to the dynamically developing mining industry, leading to a quasi-recession and dependence of the country's economy on the production and export of natural resources (Corden and Neary, 1982). This is one of the main endogenous macroeconomic causes of the resource curse. A detailed mechanism of action of the Dutch disease and resource curse was presented, among others, in (Dymitrowska, 2015).

${ }^{4}$ The first natural resource fund was established in 1953 in Kuwait (Sugawara, 2014).
} 
income is accumulated in the fund's account. If the price falls below the threshold, the deficit is financed from the fund. The optimal price of the resources is determined on the basis of an analysis of the situation on the international market and an assessment of the state budget demand (Stevens, 2003b) (Figure 1).

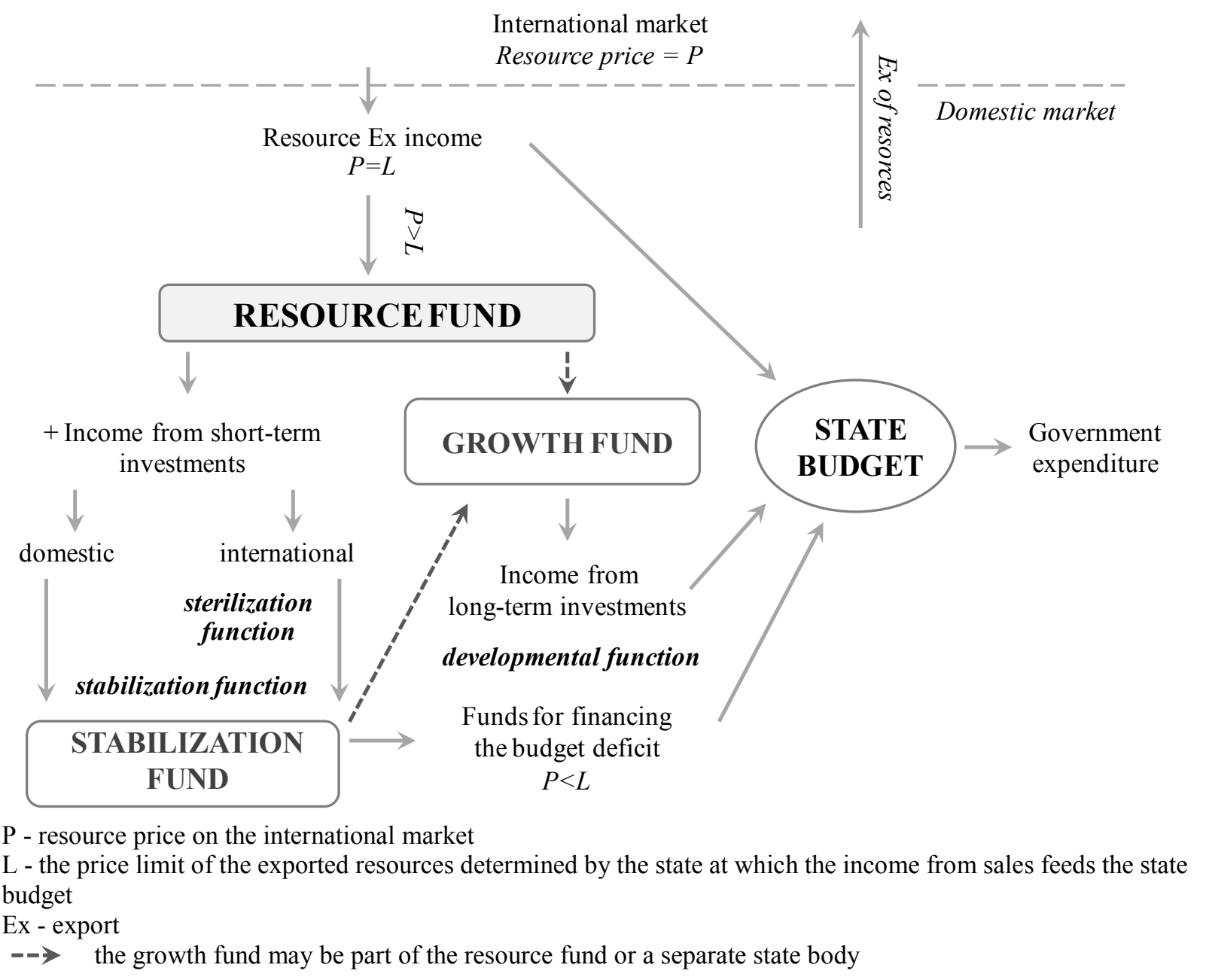

Figure 1. Resource fund functioning system. Adapted from: own study.

Contemporary NRFs, however, do not have only a stabilising function. Over the years, many different forms of natural resource funds have been created. Analysing the total of funds created, two additional functions performed in the context of counteracting the resource curse can be distinguished. The first is the sterilisation function, which is directly related to the stabilising role of the NRF. The goal is to separate the national economy from the high surplus of revenues resulting from an increase in natural resource prices during a so-called natural resource boom. The funds accumulated in the fund are not invested in the domestic market but in the foreign market. Part of the money is allocated to the purchase of short-term securities (shares and bonds), whilst other funds are often invested in highly liquid assets. Part of the natural resource revenues is invested in the country in accordance with the principle described above regarding the case of the stabilisation fund. This manner of investing the accumulated resource revenues allows the fund to perform a sterilisation and stabilisation function at the 
same time, as it guarantees the quick recovery of money in the event of a drop in the prices of natural resources and for covering the deficit created (Figure 1).

In recent years, among countries rich in natural resources, there is a trend to create a new form of the fund that has a development function (in other words, long-term saving or saving) (BRSP, 2006, p. 27). The so-called growth fund can only be part of the resource fund or constitute an independent state body. The development function consists in allocating part or all of the revenues from the sale of resources accumulated in the fund for long-term investments in diversified foreign assets so that both present and future generations can benefit from the national wealth (Figure 1). In the case of the growth fund and other forms of NRFs, it is recommended to spend the least amount of export revenues in the country. An extreme case is the allocation of only profits generated as a result of the fund's long-term investment activities to finance domestic investments. A radical form of the growth fund was used, for example, in Norway, where the Government Pension Fund Global is one of the most profitable and effective funds in the world. The long-term savings function, however, requires the formation of appropriate institutional, political and social conditions in the country. Social phenomena, such as a rent seeking, for example, often occurring in countries rich in natural resources, can be a significant obstacle to the fund's successful operation. In addition, the use of the Norwegian form of the fund in the poorest countries seems impossible. It is difficult to convince the citizens of a country that is lacking, for example, drinking water and food to set aside money earned on the sale of resources for future generations. Often, such countries are not prepared to create a fund due to the lack of an appropriate institutional framework and unstable political situation. However, it should be noted that the growth fund as an element of a policy of the national resource fund may constitute a so-called "window of opportunity", enabling diversification of the economy. Over time, the country may change its position on the international market from an exporter of natural resources to an exporter of financial capital. Reducing the level of dependence of economic development on the resource industry is one of the main tasks to counter the resource curse.

Table 1 presents examples of NRFs in accordance with their function/s.

From the information contained in Table 1, it follows that there is no one universal template for a resource fund. The common feature of an NRF is, however, the fact that the owner and entity managing the fund is the state, and the funds that are accumulated come from the sale of natural resources. This is why it is appropriate to use the term resource fund, which is a multifaceted term that combines both the concept of a stabilisation fund (including a sterilisation function) and a growth fund. The term national resource fund is also appropriate due to the state form of the fund and the domestic nature of natural resources. 
Table 1.

Examples of NRFs by function

\begin{tabular}{|c|c|c|c|c|c|c|}
\hline \multirow{2}{*}{\multicolumn{2}{|c|}{ Fund name }} & \multirow[b]{2}{*}{ Country } & \multirow[b]{2}{*}{ Founded } & \multicolumn{3}{|c|}{ Function } \\
\hline & & & & stabilisation & sterilisation & $\begin{array}{l}\text { development } \\
\text { (saving) }\end{array}$ \\
\hline \multicolumn{2}{|c|}{ Alberta Heritage Savings Trust Fund } & $\begin{array}{l}\text { Alberta, } \\
\text { Canada }\end{array}$ & 1976 & & & $\mathrm{X}$ \\
\hline \multirow{2}{*}{$\begin{array}{c}\text { Copper } \\
\text { Stabilisation } \\
\text { Fund (1985) }\end{array}$} & Pension Reserve Fund & \multirow[b]{2}{*}{ Chile } & 2006 & & & $\mathrm{X}$ \\
\hline & $\begin{array}{l}\text { Economic and Social } \\
\text { Stabilisation Fund }\end{array}$ & & 2006 & $\mathrm{X}$ & $\mathrm{X}$ & \\
\hline \multicolumn{2}{|c|}{ Government Pension Fund Global } & Norway & 1990 & & & $\mathrm{X}$ \\
\hline \multicolumn{2}{|c|}{ General Reserve Fund } & \multirow{2}{*}{ Kuwait } & 1953 & $\mathrm{X}$ & $\mathrm{X}$ & \\
\hline \multicolumn{2}{|c|}{ Future Generations Fund } & & 1976 & & & $\mathrm{X}$ \\
\hline \multicolumn{2}{|c|}{ Timor-Leste Petroleum Fund } & $\begin{array}{l}\text { Timor- } \\
\text { Leste }\end{array}$ & 2005 & $\mathrm{X}$ & $\mathrm{X}$ & $\mathrm{X}$ \\
\hline \multicolumn{2}{|c|}{ Alaska Permanent Fund } & $\begin{array}{l}\text { Alaska, } \\
\text { USA }\end{array}$ & 1976 & & & $\mathrm{X}$ \\
\hline
\end{tabular}

Adapted from: own study based on "Our Members" by the International Forum of Sovereign Wealth Funds. Copyright 2019 by IFSWF.

Thus, the resource fund (also the national resource fund, NRF) is a state entity aimed at managing the revenues obtained from the export of natural resources so as to enable stable longterm economic development of the country exporting resources.

In summary, a general functional NRF system is proposed, as illustrated in Figure 1. The figure presents the mechanism of operation of the resource fund, taking into account all the functions that it can perform. The scheme will have a different form for each specific case study of a country rich in natural resources. However, the figure illustrates the general assumptions for the functioning of an NRF and can be used as a reference for further research.

Given the multidimensionality of the concept of a resource fund, the so-called Sovereign Wealth Fund (SWF) should be mentioned, whose activity in recent years has been the subject of interest of many scientists in the fields of economics and political science, as well as international organisations and wide public opinion. The Sovereign Wealth Fund is a governmental investment (or savings) fund created to manage (invest) foreign assets so as to make profits from the accumulated funds (Aizenman, and Glick, 2009; Sun, and Hesse, 2010; Sugawara, 2014). Otherwise, the SWF can be defined as investment entities established for the long-term investment of fixed budget surpluses, coming from the export of natural resources, fiscal revenues, revenues from privatisation, foreign exchange operations and a positive balance of payments in global financial assets (Wiśniewski, 2011). The International Monetary Fund distinguishes four types of SWFs: stabilisation funds, pension reserve funds, reserve investment funds and savings funds (IMF, 2012). Literature on the subject also includes other SWF divisions, for example into stabilisation and savings funds, investing foreign exchange, development and retirement (Marchewka-Bartkowiak, 2009). Considering the source of funds accumulated, it should be stated that the resource fund described above is a form of an SWF. Depending on the tasks set before the fund, it may then perform the function or functions of stabilisation, sterilisation or development (or savings). At the same time, it should be noted that 
NRFs play a key role in Sovereign Wealth Funds, and their impact on the global financial market is significant (Urban, 2017). According to data from the Sovereign Wealth Fund Institute, the total assets of all SWFs in the world are approx. USD 7.912 billion, of which over half are NRFs (SWFI, 2019).

\section{The issue of assessing the effectiveness of NRFs in literature}

Due to the significant impact of SWFs, in particular resource funds, on global financial markets and because of their growing importance in the global economy, Sovereign Wealth Funds are the subject of interest of many scientists (e.g. Devlin, and Lewin, 2005; Aizenman, and Glick, 2009; Marchewka-Bartkowiak, 2009; Sun, and Hesse, 2010; Bagattini, 2011; Balding, 2012; Barma, 2012; Sugawara, 2014; Asik, 2017; Urban, 2017). Part of the research was focused on analysing the effectiveness of NRFs in the category of counteracting the resource curse (including Fasano, 2000; Devlin, and Titman, 2004; Devlin, and Lewin, 2005; Shabsigh, and Ilahi, 2007; Ossowski et al., 2008; Barma et al., 2012; Sugawara, 2014; Dymitrowska, 2015; Asik, 2017).

In most of the work devoted to NRF issues, the effectiveness of the fund's stabilisation function is primarily examined. The methodology adopted in individual studies is varied, which affects the differences in the results presented. Some studies focused on case studies of individual countries, while others used data from a number of resource-rich countries. For example, Fasano (2000) analysed six rich regions (Norway, Chile, Venezuela, Kuwait, Oman and Alaska (USA)), assessing the effectiveness of NRFs based on an analysis of the effectiveness of the isolation of domestic expenditure from export revenues of natural resources. It was found that the results differ depending on the specific case of the country, the adopted principles of the fund's operation and the quality of the NRF policy. The importance of the resource fund as a means of stabilising government spending in the group of resourcerich countries was also assessed in the work of Davis et al. (2001). The presented results are not conclusive. While analysing the effectiveness of the stabilisation function of NRFs, some researchers (e.g. Clemente et al., 2002; Merlevede et al., 2009) took into account, apart from the manner of shaping government spending, the general stabilisation of the economic situation in the country. Crain and Devlin (2002), analysing data on 71 countries in the years 1970-2000, took into account the level of government spending, as well as economic and demographic results obtained in the studied economies. The positive impact of NRFs on reducing the volatility of economic development, especially in countries specialising in oil exports, was confirmed. Shabsigh and Ilahi (2007) also took into account changes in inflation and the real exchange rate. The survey results confirm the negative impact of funds on the level of the indicators analysed. In the work of Ossowski et al. (2008), three measures of fiscal results 
of the state were used: primary balance excluding results of the oil industry, increase in government expenditure and ratio between changes in government expenditure and oil prices. The results of the study are not conclusive. Attention was, however, paid to the importance of institutional conditions (including stability of the political situation, level of corruption and rent seeking) for effective operation of the NRF policy. It was found that the higher the quality of institutions created in the country, the more stable the country's economic situation. The importance of the institutional framework under the issue of effective operation of stabilisation funds was also highlighted in the study by Frankel, Vegh and Vuletin (2012).

Bagattini (2011) analysed 12 countries with functioning resource funds for the years 1992-2007 taking into account the indicator based on six variables: level and change in the general budget balance, level and change in the budget balance without the participation of the natural resource industry, change in non-resource revenues and change in public debt. The presented results confirmed the effectiveness of NRFs as a means of counteracting the instability of fiscal policy and the increase in the level of public debt. At work, as in the case of Ossowski et al. (2008) and Frankel, Vegha and Vuletina (2012), attention was drawn to the essence of political stability in the country and the quality of fund management, including transparency and responsible operation of the NRF.

Sugawara (2014) set the main goal of his study to determine the importance of the stabilisation fund in reducing the volatility of expenditure in countries rich in natural resources. As a result of the analysis of 68 countries over a 25 -year period, he found that the countries in which the stabilisation fund was created are characterised by greater stability of government spending. He also found that there was a negative relationship between the fund's operation and the lack of stability in total expenditure. In addition to assessing changes in government expenditure and total expenditure, the study took into account the following categories: the structure of the economy, economic management, the financial market and the political institution.

Asik (2017) focused his attention on analysing the impact of funds on levelling the instability of the economic situation in a resource-rich country and filling the counter-cyclical nature of the state's fiscal policy. After conducting the study, based on data from 29 countries specialising in the export of crude oil for the years 1980-2012, he presented a conclusion confirming the effectiveness of NRFs. The concept of efficiency referred to the degree of fiscal countercyclicality, taking into account the goal of smoothing fiscal revenues and expenses by creating a savings tool in the form of a resource fund. The following indicators were taken into account: volatility of the level of real household consumption, real government expenditure, as well as gross capital investment. An additional analysis was also carried out taking into account the assessment of the premises for the creation of an NRF and the importance of the institutional framework formed. An important proposal was also made to assess the nature of changes in government spending. It was found that it is important to analyse whether the trend of changes in spending is constant and does not depend on changes on the global natural 
resources market rather than assessing whether expenses are at a constant level, as economic growth, often associated with increased state investment, is high in countries with significant developmental demand. According to the author, it is important not to stop the increase in state spending, but to maintain a stable trend of their changes.

When analysing literature on the subject of assessing the effectiveness of NRFs, two documents developed in recent years should be mentioned. The first is the so-called Santiago Principles. In 2009, due to the growing attention paid to SWF activities, a group of 23 leading global sovereign investors created the International Forum of Sovereign Wealth Funds, a global non-profit organisation of sovereign wealth funds involved in cooperation and strengthening SWF communities through dialogue, research and self-evaluation. During the Summit in Chile in September 2008, the Forum, in cooperation with international institutions such as the G20, the International Monetary Fund and the US Department of the Treasury, distinguished 24 general principles and practices (Santiago Principles) that form the basis of an effective SWF. The proposed rules are aimed at promoting good management, costeffectiveness, transparency and prudent investment practices of the fund. The Santiago Principles are guidelines that should be followed by the management board of an SWF in order to maintain a stable global financial system, proper risk control and a sound fund management structure (IWG, 2008). The proposed document contains rules regarding the operation of Sovereign Wealth Funds. However, due to the fact that a significant part of SWFs are resource funds, it is justified to include the Santiago Principles in the overall assessment of NRF effectiveness.

As part of the analysis of the measures of the effectiveness of resource funds, the Natural Resource Charter presented by the Natural Resource Governance Institute (NRGI, 2019) should also be mentioned. The Charter is a set of principles developed upon the initiative of the International Monetary Fund and the World Bank by a group of independent practitioners and academic staff for governments and societies of countries rich in natural resources. The document provides guidance on how to best use the opportunities created by the extraction of resources for economic development. The assumptions presented in the Natural Resources Charter concern the general principles of conducting a state's economic policy aimed at counteracting the resource curse. As with the Santiago Principles, they can, however, be useful in assessing the effectiveness of NRFs in countries rich in natural resources.

Analysing literature on the subject devoted to the issue of the effectiveness of resource funds in counteracting the resource curse, it should be confirmed that the results presented are inconclusive, the adopted methodological assumptions are not uniform, and NRFs are often evaluated solely in terms of fulfilling the stabilising function. Most studies mention the paradox of plenty, but superficially, focusing primarily on the volatility of commodity prices and the increase in budget spending as the main reasons for its occurrence. The resource curse is, however, a complex and multidimensional phenomenon. It is important to refer individual functions of the resource fund to the main symptoms of the paradox and then to determine the indicators for assessing the effectiveness of an NRF. 


\section{Indicators of NRF performance evaluation}

Literature on the subject (Dymitrowska, 2015, p. 74) identifies four main macroeconomic reasons for the occurrence of the paradox of plenty, making up the so-called vicious circle of the resource curse (Figure 2) - two endogenous: Dutch disease and the economy's dependence on the resource industry, and two exogenous: volatility of resource prices and long-term deterioration of Terms of Trade (ToT).

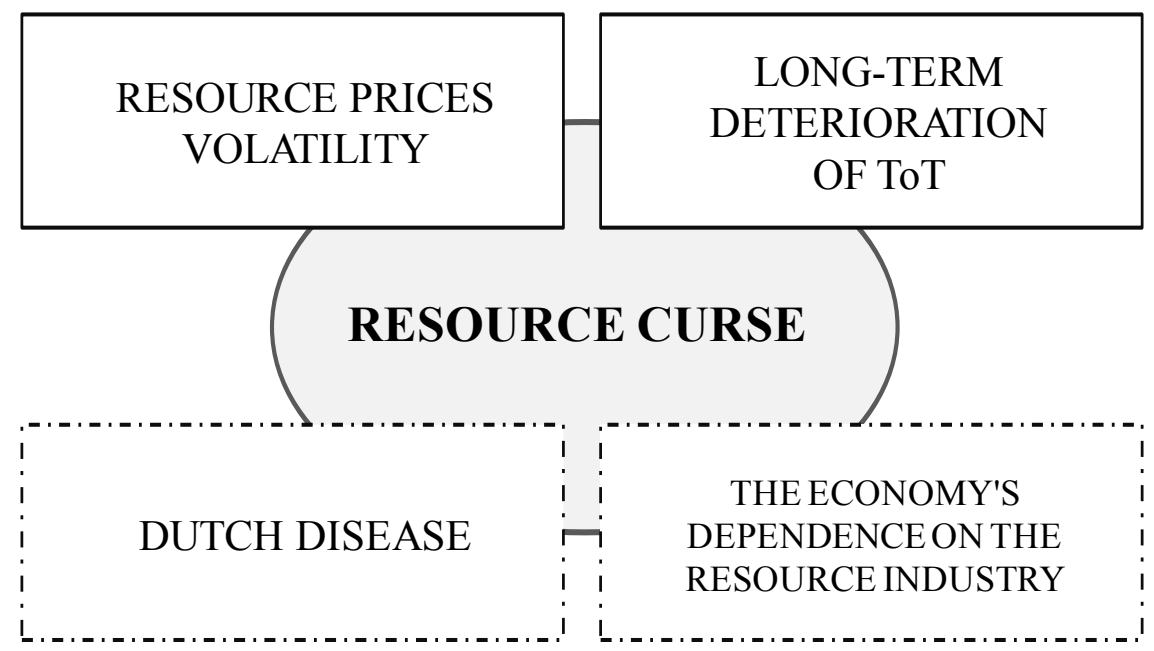

Figure 2. Vicious circle of the resource curse. Adapted from: "Klątwa bogactwa a polityka gospodarcza państwa" by Y. Dymitrowska. Copyright 2015 SimplePublishing.

The determinants of the resource curse are closely related. Exogenous factors lead to a paradox of plenty in the case of a significant dependence of a country's economy on the extraction and export of natural resources. At the same time, fluctuations in resource prices contribute to the emergence of the Dutch disease, which results in the long-term dependence of a country's economy on the mining sector. The overall objective of the resource fund is to provide long-term stable economic growth of a country which exports natural resources, which is equivalent to counteracting the resource curse. Stabilisation funds, which perform a stabilisation function and usually sterilisation as well, are primarily aimed at not making the domestic economy dependent on unstable price changes on the global natural resource market. The main task of stabilisation funds is therefore to directly influence two factors of the curse volatility of natural resource prices and the resulting Dutch disease (Figure 3). A similar approach was presented in the study of Ossowski et al. (2008) and Bagattini (2011). Indirectly, the fulfilment of these functions also leads to levelling the long-term deterioration of ToT and to reducing the dependence of a country's economy on the resource industry. However, it should be noted that the last two determinants are not a direct task of the stabilisation fund, the main role of which is to stabilise the economic situation in the country and immunise the economy against so-called resource booms. Many funds established in those poorest countries rich in natural resources primarily play a stabilising role. Therefore, as already mentioned, 
the fulfilment of the stabilisation task is most often analysed when examining the fund's effectiveness.

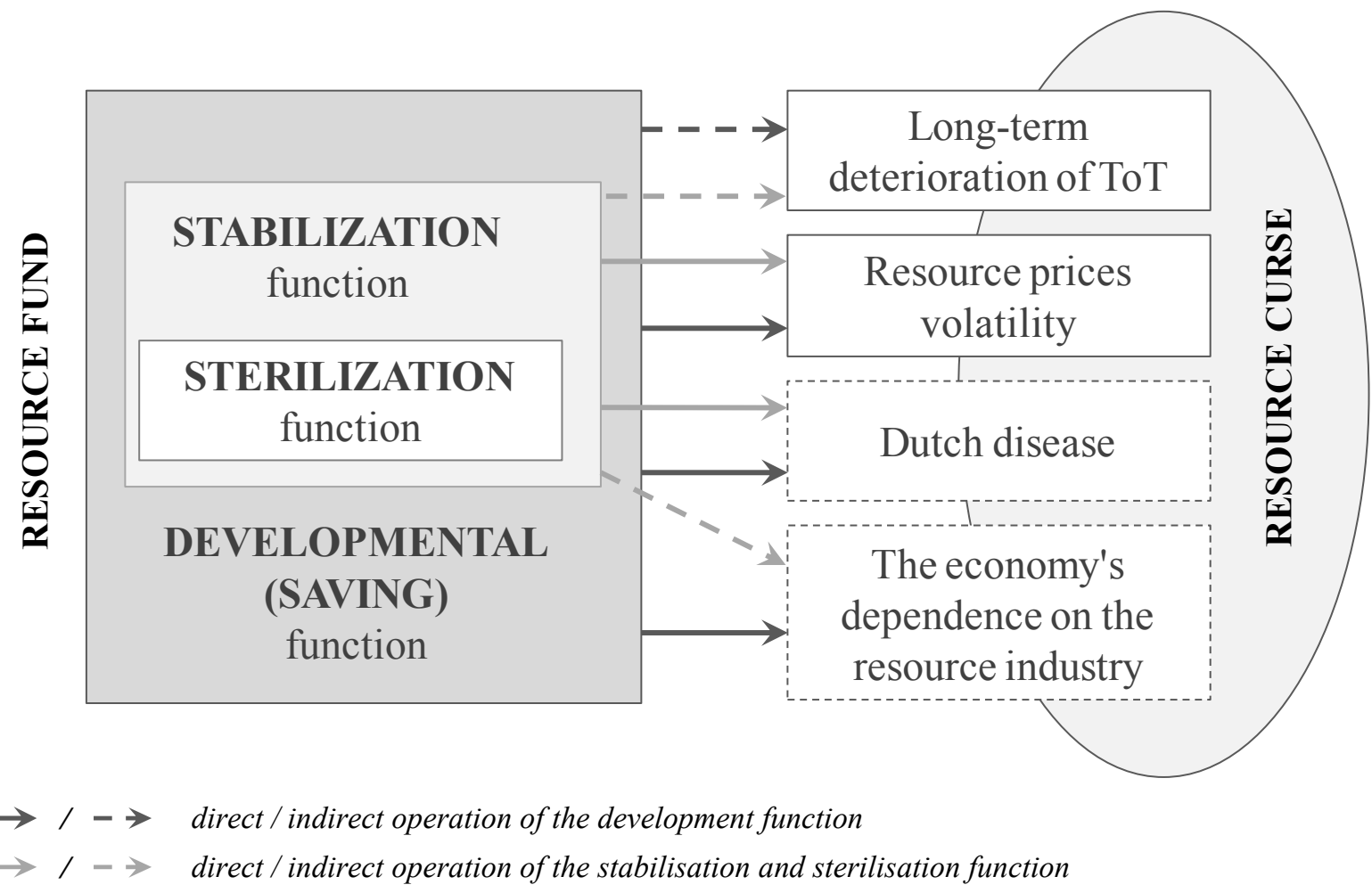

Figure 3. Relating the NRF function to the determinants of the resource curse. Adapted from: own study.

The growth fund, which mainly fulfils the development (savings) function of the NRF, although operating in a different manner to the stabilisation fund, also aims to stabilise the longterm economic development of the country, and thus it directly affects the instability of prices of natural resources and Dutch disease (Figure 3). This means that the growth fund also acts as a stabilisation fund. However, it should be noted that there is no inverse relationship. The funds accumulated in the stabilisation fund are invested in short-term assets, which means that the fund does not fulfil the function of long-term savings. Fulfilling the pro-development role of the growth fund also allows for diversification of the economy in the long term by changing the country's position from an exporter of natural resources to an exporter of financial capital, consequently reducing the dependence of economic development solely on the operations of the mining industry. Therefore, the operation of the development function of the NRF on the level of dependence of the economy on the natural resource industry should be defined as direct.

The long-term deterioration of ToT is both the cause and the result of the resource curse. Therefore, the impact of an NRF policy on this factor in each of the functions considered is indirect. The theory of long-term deterioration of ToT in the context of the resource curse is largely related to the thesis of Prebisch/Singer (Prebisch, 1950; Singer, 1950), according to which a country whose economy depends only on the production of natural resources and/or basic goods, in the long run, is able to import fewer and fewer investment products, which slows its long-term development. Due to the fact that in recent years there have been studies 
confirming the validity of Prebish/Singer's thesis (e.g. Harvey et al., 2010; Rynarzewski, 2013), it should be included in the analysis of the resource curse. However, due to the indirect nature of the discussed factor, its importance in the context of analysing the effectiveness of an NRF is negligible.

Depending on the function of a resource fund, the effectiveness of its operation should be tested differently. At the same time, it should be remembered that the growth fund fulfils the tasks of a stabilisation fund. A list of indicators enabling the assessment of a fund's effectiveness in the category of the resource curse depending on the functions and tasks assigned to the fund is presented in Table 2 .

Table 2.

List of indicators enabling the assessment of NRF effectiveness in the category of the resource curse

\begin{tabular}{|c|c|c|c|}
\hline & FUNCTION & MAIN TASKS & $\begin{array}{c}\text { INDICATORS TO ASSESS THE IMPLEMENTATION } \\
\text { OF THE TASKS }\end{array}$ \\
\hline & & & change in the level of government spending \\
\hline & Stabilisation & $\begin{array}{l}\text { stabilisation of government } \\
\text { spending }\end{array}$ & $\begin{array}{l}\text { comparing the change in the level of government } \\
\text { spending with the change in income from resource } \\
\text { exports and the change in prices of natural resources on } \\
\text { the global market }\end{array}$ \\
\hline & & counteracting Dutch dicease & change in real non-resource GDP per capita \\
\hline & & counteracting Dutcn aisease & change in added value of non-resource sectors \\
\hline & Sterilisation & $\begin{array}{l}\text { isolating the economy from } \\
\text { surplus revenues from } \\
\text { export of natural resources }\end{array}$ & fund structure (level of domestic and foreign investments) \\
\hline 它 & & $\begin{array}{l}\text { increasing long-term public } \\
\text { savings }\end{array}$ & $\begin{array}{l}\text { change in the level of funds accumulated in the fund } \\
\text { (value of the fund) }\end{array}$ \\
\hline 厌 & & - & fund investment return rate \\
\hline 空 & Developmental & $\begin{array}{l}\text { increasing long-term state } \\
\text { investment }\end{array}$ & $\begin{array}{l}\text { change in the level of long-term foreign investments } \\
\text { carried out by the fund }\end{array}$ \\
\hline ஜ & (savings) & $\begin{array}{l}\text { diversification of the } \\
\text { economy in the form of }\end{array}$ & $\begin{array}{l}\text { number of enterprises in the fund's portfolio, number of } \\
\text { host countries, position of the fund in rankings }\end{array}$ \\
\hline & & a change of role from an & GDP structure \\
\hline & & $\begin{array}{l}\text { exporter of resources to an } \\
\text { exporter of financial capital }\end{array}$ & structure of the state budget \\
\hline & & & change in real GDP per capita \\
\hline & & & change of the HDI coefficient level \\
\hline & Other indirect & $\begin{array}{l}\text { stable long-term economic } \\
\text { development of the country } \\
\text { (in the context of the } \\
\text { resource curse) }\end{array}$ & $\begin{array}{l}\text { level of dependence of the economy on the mining } \\
\text { industry (average annual revenues of the mining industry } \\
\text { (in \% of GDP), average annual exports of natural } \\
\text { resources (in \% of total exports), average annual revenues } \\
\text { of the mining industry (in \% of total state budget income)) }\end{array}$ \\
\hline & & & change in society's income disparity (Gini coefficient) \\
\hline & & $\begin{array}{l}\text { transparent and responsible } \\
\text { operation of the fund }\end{array}$ & fulfilment of the Santiago Principles \\
\hline
\end{tabular}

Adapted from: own study.

The stabilising function of the natural resource fund assumes the stabilisation of revenues from the export of natural resources, the stabilisation of expenditure in the country and indirectly counteracting Dutch disease and enabling stable long-term economic development. Considering the essence of the NRF, which is a state entity, as the main stabilisation task, 
it is necessary to specify the stabilisation of budget expenditure so that the budget can be made independent of changes in the level of income from resource exports and from prices of natural resources on the global market. An indicator enabling the assessment of the implementation of the stabilisation task is the change in the level of government spending. It is reasonable to simultaneously adopt the assumption presented by Asik (2017) about the importance of stability of government spending, rather than maintaining its constant level. Developing countries are characterised by rapid economic growth, often associated with increasing state investment. Therefore, it is important that the fiscal policy of the state is stable and balanced and that the trend in shaping government spending does not show any breakdowns occurring on the global natural resource market. When analysing the effectiveness of the fund's countercyclical operation, it is important to compare the change in the level of government spending with the change in income from resource exports and the change in prices of natural resources on the global market.

Dutch disease is one of the main macroeconomic endogenous causes of the resource curse. At the same time, it is the first alarming symptom resulting from the lack of stability in the international commodity market. Therefore, in the context of the stabilisation function performed by the fund, it is important to assess the occurrence of signs of the disease in the country. Due to the fact that the phenomenon discussed relates to the takeover of the dominant role on the domestic market by the mining industry and a decrease in competitiveness, a reduction of activity level and often the bankruptcy of enterprises from other industries with a simultaneous increase in real GDP in the country by universal indicators enabling assessment of the appearance of the Dutch disease, there is a change in real non-resource GDP per capita and a change in the added value of non-resource sectors. The above-mentioned indicators make it possible to estimate whether domestic income is driven exclusively by the mining industry or also by the development of other industries. At the same time, it should be noted that the expected result is not necessarily an increase in the indices presented, but no sharp decline. An analysis of non-resource GDP per capita and the change in the added value of non-resource sectors allows for a preliminary assessment of the occurrence of Dutch disease ${ }^{5}$.

The NRF sterilisation function is directly related to the stabilisation task and consists in increasing the resistance of the national economy to the consequences of natural resource booms. Assessment of the sterilisation task can be done by analysing the fund structure. The greater the share of foreign investment in NRF activities, the more the sterilisation function is fulfilled.

When analysing the effectiveness of the growth fund, all the aforementioned indicators should be taken into account. In addition, the fund is designed to increase long-term public savings and increase long-term state investment. Assessment of the achievement of the set goals

\footnotetext{
${ }^{5}$ In order to carry out more detailed research, a number of additional indicators can be used, presented for example in the study (Dymitrowska, 2015, p. 75).
} 
can be made through a detailed analysis of the state and the international position of the fund by estimating the value of the fund and the change in the level of accumulated funds over time, the rate of return on the fund's investments and the degree of long-term foreign investments implemented. Enabling the diversification of the economy by changing the role of the country on the international market from an exporter of natural resources to an exporter of financial capital can be assessed by analysing the number of enterprises in the growth fund portfolio and the number of host countries, as well as estimating the position of the NRF in the international rankings of the largest SWFs in the world.

The policy of the national resource fund assumes a direct impact on the level of state expenditure and the occurrence of Dutch disease and, in the case of the growth fund, also on reducing the economy's dependence on the mining industry. Due to the fact that the fund does not actually play a strict role in the context of any further economic policy pursued by the state, long-term economic development should be included in the additional indirect objectives of the NRF. In the context of the resource curse when assessing the economic development of countries specialising in the export of natural resources, apart from the indicators distinguished in the analysis of Dutch disease, one should take into account the change in real GDP per capita, the change in the HDI ratio, the level of dependence of the economy on the mining industry (based on the average annual revenues of the mining industry (in \% of GDP), the average annual exports of natural resources (in \% of total exports), the average annual revenues of the mining industry (in \% of total state budget income)) and any change in the society's income disparity (based on the Gini coefficient).

When analysing the effectiveness of NRFs in literature on the subject, the importance of transparent and responsible operation of the fund is often emphasised. Therefore, when assessing the fund's effectiveness, it is important to evaluate its performance in this category. The level of good management, transparency and prudent investment practices of the fund can be determined by comparing the NRF operating standards with the Santiago Principles.

\section{Conclusions}

The natural resource fund is a tool of a state's economic policy, consisting in the creation of a state entity aimed at managing revenues from the export of natural resources in such a way as to enable stable, long-term economic development of a country exporting resources. Due to the state form of the fund and the national nature of natural resources, an appropriate name is also the national resource fund. In the case of resource-rich countries, enabling sustainable economic development is tantamount to counteracting the resource curse, consisting in slower economic development in countries specialising in the export of natural resources compared to countries whose resources are scarce. 
The main function performed by the NRF is a stabilising function, which is aimed at separating the domestic economy from unstable changes taking place on the global natural resource market. The stabilisation function also consists in creating a so-called buffer retaining significant revenues from the export of natural resources before their massive inflow into the country, leading to Dutch disease and the resource curse in the long run. The NRF sterilisation function further strengthens the protective effect by investing accumulated funds on foreign markets. The two NRF functions presented are closely related.

The most advanced form of the natural resource fund is the growth fund, which, apart from stabilising and sterilising functions, also takes on the task of long-term savings. All funds collected from the sale of natural resources are allocated for long-term investments on foreign markets. The country uses only profits generated by the fund's activities. The growth fund may be part of the NRF, under which the funds are divided between the stabilisation and growth fund or a separate state body. An extreme approach is to establish only a pro-development form of the fund, as was done e.g. in Norway. In the poorest countries specialising in the extraction and export of natural resources, this solution seems to have little effect, although the results of the research are not clear. Due to the emergence of new funds from developing countries on the international NRF market, e.g. the East Timor Oil Fund, the issue of the efficiency of the operation of natural resource funds in the poorest countries should be subjected to detailed analysis as part of future research. It should also be noted that the growth fund has a stabilising function, but there is no inverse relationship. The creation of a long-term savings fund also provides the opportunity to diversify the economy by changing the country's role in the long term from a natural resources exporter to a financial capital exporter.

National natural resource funds are a form of sovereign wealth funds, but they play a key role within the SWF. The importance of NRFs on the global financial market is constantly growing, so the problem of their effective operation is important both from the point of view of the interest of natural resource exporters and the stability of the global economy. The results of empirical research devoted to assessing the effectiveness of the functioning of funds are not explicit. As part of the analyses, different research assumptions are adopted, and various efficiency measures are used. The key goal of this study was to distinguish indicators that allow for assessing the effectiveness of natural resource funds in the context of the resource curse in countries rich in natural resource deposits. The indicators identified on the basis of a thorough analysis of literature on the subject, depending on the functions and tasks assigned to the fund, are presented in Table 2 . The presented measures have practical significance. They can be used in further research aimed at assessing the effectiveness of NRFs in both the group of countries rich in natural resources and in individual case studies. An additional cognitive value of the article is the system of natural resource funds presented in Figure 1, as well as the reference of individual NRF functions to the determinants of the resource curse (Figure 3). 


\section{References}

1. Acemoglu, D., Johnson, S., and Robinson, A. (2001). The colonial origins of comparative development: an empirical investigation. American Economic Review, 91.

2. Aizenman, J., and Glick, R. (2009). Sovereign Wealth Funds: Stylized Facts about their Determinants and Governance. International Finance, 12/3.

3. Arezki, R., and Van der Ploeg, F. (2007). Can the natural resource curse be turned into a blessing? The role of trade policies and institutions. CEPR Discussion Paper, 6225.

4. Auty, R.M. (1993). Sustaining Development In Mineral Economies: The Resource Curse Thesis. London: Routledge.

5. Auty, R.M. (2001). Resource abundance and economic development. Oxford: Oxford University Press.

6. Bagattini, G.Y. (2011). The Political Economy of Stabilisation Funds: Measuring their Success in Resource-Dependent Countries. Brighton: Institute of Development Studies, University of Sussex, IDS Working Paper, 356.

7. Barma, N.H., Kaiser, K., Le, T.M. and Viñuela, L. (2012). Rents to Riches? The Political Economy of Natural Resource-Led Development. Washington D.C.: World Bank.

8. BRSP (2006). Meeting the Challenge of the Resource Curse. International Experiences in Managing the Risks and Realising the Opportunities of Non-Renewable Natural Resource Revenue Management. London: Programme on Business and Development Performance, United Nations Development Programme, Overseas Development Institute.

9. Bulte, E., Damania, R., and Deacon, R. (2005). Resource Intensity, Institutions, and Development. World Development, Elsevier, 33.

10. Clemente, L., Faris, R., and Puente, A. (2002). Natural Resource Dependence, Volatility and Economic Performance in Venezuela: The Role of a Stabilization Fund. Cambridge: Andean Competitiveness Project Working Paper, Center for International Development, Harvard University.

11. Corden, W.M., and Neary, J.P. (1982). Booming sector and de-industrialization in a small open economy. Economic Journal, 92.

12. Crain, W.M., and Devlin, J. (2002). Nonrenewable Resource Funds: A Red Herring for Fiscal Stability? Washington D.C.: World Bank, Draft working paper.

13. Davis, J., Ossowski, R., Daniel, J., and Barnett, S. (2001). Stabilization and savings funds for non-renewable resources. International Monetary Fund, Occasional paper, 205.

14. Devlin, J., and Lewin, M. (2005). Managing Oil Booms and Busts in Developing Countries. In: J. Aizenman, and B. Pinto (Eds.), Managing Economic Volatility and Crises: A Practitioner's Guide. New York: Cambridge University Press.

15. Dymitrowska, Y. (2015). "Klatwa bogactwa" a polityka gospodarcza państwa. Poznań: SimplePublishing. 
16. Fasano, U. (2000). Review of the Experience with Oil Stabilization and Savings Funds in Selected Countries. Washington D.C.: International Monetary Fund, IMF Working Paper, $00 / 112$.

17. Fasano, U. (2002). With open economy and sound policies, U.A.E. has turned oil "curse" into a blessing. IMF Survey, 31.

18. Frankel, J. (2010). The Natural Resource Curse: A Survey. Cambridge: Harvard Environmental Economics Program, Discussion Papers, 21, Harvard Kennedy School, Harvard University.

19. Frankel, J., Vegh, C., and Vuletin, G. (2012). On Graduation from Fiscal Procyclicality. Journal of Development Economics, 100/1.

20. Harvey, D.I., Kellard, N.M., Madsen, J.B., and Wohar M.E. (2010). The Prebisch-Singer Hypothesis: Four Centuries of Evidence. The Review of Economics and Statistics, 92.

21. IFSWF (2019). International Forum of Sovereign Wealth Funds, Our Members. Available online https://www.ifswf.org/our-members, 19.09.2019.

22. IMF (2012). Global Financial Stability Report: The Quest for Lasting Stability. Washington D.C.: World Economic and Financial Surveys, International Monetary Fund.

23. IWG (2008). Sovereign Wealth Funds Generally Accepted Principles and Practices „Santiago Principles”. International Working Group of Sovereign Wealth Funds.

24. Krueger, A. (1974). The Political Economy of the Rent-Seeking Society. American Economic Review, American Economic Association, 64.

25. Larsen, E.R. (2005). Are rich countries immune to the resource curse? Evidence from Norway's management of its oil riches. Resources Policy, Elsevier, 30.

26. Marchewka-Bartkowiak, K. (2009). Państwowe fundusze stabilizacyjne - problem czy szansa na długoterminowe równoważenie budżetu państwa. In: A. Szewczuk (Ed.), Finanse 2009 - Teoria i praktyka, Finanse publiczne, I. Szczecin: Wydawnictwo Naukowe Uniwersytetu Szczecińskiego.

27. Merlevede, B., Schoors, K., and Van Aarle, B. (2009). Russia from Bust to Boom and Back: Oil Price, Dutch Disease and Stabilisation Fund. Comparative Economic Studies, 51/2.

28. Mikesell, R.F. (1997). Explaining the resource curse, with special reference to mineral exporting countries. Resource Policy, 23.

29. Neumayer, E. (2004). Does the "Resource Curse" Hold for Growth in Genuine Income as Well? World Development, Elsevier, 32.

30. NRGI (2019). Natural Resource Governance Institute, Natural Resource Charter. Available online https://resourcegovernance.org/approach/natural-resource-charter, 19.09.2019.

31. Ossowski, R., Villafuerte, M., Medas, P.A., and Thomas, T. (2008). Managing the Oil Revenue Boom: The Role of Fiscal Institutions. Washington D.C.: International Monetary Fund, IMF Occasional Paper, 260.

32. Prebisch, R. (1950). The economic development of Latin America and its principal problems. New York: United Nations, Lake Success. 
33. Rasiah, R., and Shari, I. (2001). Market, government and Malaysia's new economic policy. Cambridge Journal of Economics, 25.

34. Rynarzewski, T. (2013). Refleksje o dylematach wpływu handlu zagranicznego na rozwój gospodarczy krajów słabo zaawansowanych ekonomicznie. Studia Oeconomica Posnaniensia, 1.

35. Sachs, J.D., and Warner, A.M. (2001). Natural Resources and Economic Development. The curse of natural resources. European Economic Review, Elsevier, 45.

36. Sarraf, M. and Jiwanji, M. (2001). Beating the resource curse: the case of Botswana. Environmental Economics Series, 83/291.

37. Shabsigh, G., and Ilahi, N. (2007). Looking Beyond the Fiscal: Do Oil Funds Bring Macroeconomic Stability? Washington, D.C.: International Monetary Fund, IMF Working Paper, 07/96.

38. Singer, H.W. (1950). The distribution of gains between investing and borrowing countries. American Economic Review, 40.

39. Stevens, P. (2003a). Resource Impact: Curse or Blessing? A literature survey. Dundee: Centre for Energy, Petroleum and Mineral Law and Policy, University of Dundee.

40. Stevens, P. (2003b). Resource Impact: A curse or a blessing? Dundee: Centre for Energy, Petroleum and Mineral Law and Policy, University of Dundee.

41. Stijns, J. (2005). Natural resource abundance and economic growth revisited. Resources Policy, Elsevier, 30.

42. Sugawara, N. (2014). From Volatility to Stability in Expenditure: Stabilization Funds in Resource-Rich Countries. Washington, D.C.: International Monetary Fund, IMF Working Paper, WP/14/43.

43. Sun, T., and Hesse, H. (2010). Sovereign Wealth Funds and Financial Stability: An EventStudy Analysis. In: S.D. Udaibir, A. Mazarei, and H. van der Hoorn (Eds.), Economics of Sovereign Wealth Funds: Issues for Policymakers. Washington D.C.: International Monetary Fund.

44. SWFI (2019). Top 81 Largest Sovereign Wealth Fund Rankings by Total Assets, Sovereign Wealth Fund Institute, Fund Rankings, SWF, Available online https://www.swfinstitute.org/fund-rankings/sovereign-wealth-fund, 19.08.2019.

45. Urban, D. (2017). Państwowe Fundusze Majątkowe. Pomiędzy krajowa gospodarka a globalnymi rynkami finansowymi. Łódź: Wydawnictwo Uniwersytetu Łódzkiego.

46. Usui, N. (1997). Dutch disease and policy adjustments to the oil boom: a comparative study of Indonesia and Mexico. Resources Policy, 23.

47. Wiśniewski, P. (2011). Ekspansja państwowych funduszy majątkowych a nowy protekcjonizm inwestycyjny w gospodarce światowej. Część I. Definicja, klasyfikacja oraz istotność SWF w gospodarce światowej. Warszawa: Studia I Prace Kolegium Zarządzania i Finansów SFH, Zeszyt Naukowy nr 111, SGH.

48. Wright, G., and Czelutsa, J. (2002). Resource-based economic growth, past and present. Stanford University. 